\title{
THE DISASTER TREE
}

In the land of the blind

the shade of this tree stretches

farther than the eye can see.

Its roots run deeper than mere defoliation

knows; and even diseased and cut to a stump, the least half-inch left

level on dirt is the base of a magic space

leading the eyes up

the tree the blind see, to where its invisible

birds sing inaudible notes of hope;

its xylem are still cocked toward heaven.

And even when we fall to our knees

the paper-thin skin

covering the patella is a minimal cushion we mustn't deny, for in retrospect

it suffices. This poem written on the dead

trunk, on paper, is for the deflowered flower-girl whose boyfriend may yet do her justice, insurance, legal heirs, and joy; this poem is for the proposing boyfriend

whose kneel is forced, but who may one day rise into his wife with a true love, the force of which needed such a long distance runner's start; this poem to say the depths

of despair are where the lowest root drinks underground streams, and continues past disaster; this, a love poem; this extended conceit, a note of hope:

the tree surgeon falling limb to limb:

when he lost his eyes, he read bark with his fingers. And when he sawed off his hand, the stump of his arm could still point, and beckon, and stroke. 